\title{
Pendampingan Pencatatan Transaksi Dan Penyusunan Laporan KeuanganBadan Usaha Milik Desa (Bumdes) Putra Subagyo Desa Miagan - Jombang
}

\author{
Rita Mutiarni \\ rita.dewantara@gmail.com \\ Siti Zuhroh \\ zuhroh.stie@gmail.com \\ Langgeng $P$ Utomo \\ lan99en9.pu36@gmail.com
}

STIE PGRI Dewantara Jombang

\begin{abstract}
abstrak
Badan Usaha Milik Desa (BUMDes) Putra Subagyo yang terletak di desa Miagan, kecamatan Mojoagung, Jombang, termasuk dalam kategori jenis usaha jasa karena kegiatan yang dilakukan adalah persewaan terop dan sound system untuk keperluan pesta. Dalam perkembangannya, pengelolaan keuangan di Badan Usaha Milik Desa (BUMDes) Putra Subagyo sudah cukup baik. Namun, para pengurus Badan Usaha Milik Desa (BUMDes) masih kesulitan untuk mencatat transaksi hingga menyusun laporan keuangan dengan benar yang sesuai dengan standar akuntansi untuk perusahaan jasa untuk jenis usaha jasa. Karena itu, tim pendamping memberikan pelatihan dan pendampingan pencatatan transaksi hingga penyusunan laporan keuangan hingga akhir tahun 2017. Dari hasil kegiatan tersebut, mitra (pengurus Badan Usaha Milik Desa) telah memahami dan mampu melanjutkan untuk tahun buku 2018.
\end{abstract}

Kata kunci: Badan Usaha Milik Desa (BUMDes), Miagan, Sewa Terop, Sound System, Pencatatan Transaksi, Laporan Keuangan

\begin{abstract}
Village Owned Enterprise (BUMDes) Putra Subagyo located in Miagan village, Mojoagung sub-district, Jombang, is included in the category of service business because the activities performed are rental of party shelter and sound system for party purposes. In its development, financial management in Village Owned Enterprise (BUMDes) Putra Subagyo is good enough. However, the Board of Directors of BUMDes still find it difficult to record transactions until they prepare the financial statements correctly in accordance with accounting standards for service companies for the type of service business. Therefore, the companion teams provide training and recruitment of transaction recording until the preparation of financial statements until the end of 2017. From the results of these activities, partners (managers of Village Owned Enterprises) have understood and are able to continue for the fiscal year 2018.
\end{abstract}

Keywords: Village Owned Enterprise (BUMDes), Miagan, Lease Party shelter, Sound System, Transaction Recording, Financial Statement

\section{A. PENDAHULUAN \\ 1. Latar Belakang}

Program pemberdayaan ekonomi dan peningkatan jaminan social masyarakat desa sudah semenjak lama dijalankan oleh Pemerintah melalui berbagai program. Namun upaya itu belum membuahkan hasil yang memuaskan sebagaimana diinginkan 
bersama. Banyak faktor yang mempengaruhi keberhasilan program-program ini dimasyarakat, beberapa hal diantaranya adalah:

1. Program pemberdayaan ekonomi yang masih bersifat parsial dan sektoral,

2. Mensyaratkan pembentukan lembaga (unit pelaksana), yang tidak jarang tugas dan fungsinya tidak jauh berbeda dengan lembaga yang dibentuk pada program yang lain.

3. Berusia pendek dan belum bersifat berkelanjutan, jika program berakhir maka berakhir juga kerja lembaga tersebut Permasalahan ego-sektoral dari lembagalembaga tersebut tidak jarang menjadi permasalahan baru di desa. Daripada bertujuan untuk meningkatkan kemandirian ekonomi masyarakat, tidak jarang lembaga ekonomi tersebut harus tumpang tindih dengan lembaga ekonomi yang lain.

Belajar dari kurang efektifnya pelaksanaan program yang sudah ada, satu pendekatan baru yang diharapkan mampu menstimuli dan menggerakkan roda perekonomian di pedesaan adalah melalui penyatuan pengelolaan kelembagaan ekonomi yang ada. Asset ekonomi yang ada didesa harus dikelola sepenuhnya oleh masyarakat desa. Bentuk kelembagaan sebagaimana disebutkan di atas dinamakan Badan Usaha Milik Desa (BUMDes). Badan usaha ini sesungguhnya telah diamanatkan di dalam UU No.32 Tahun 2004 tentang Pemerintahan Daerah (bahkan oleh undang-undang sebelumnya, UU 22/1999) dan Peraturan Pemerintah (PP) no. 71 Tahun 2005 Tentang Desa. Dalam UU Nomor 32 Tahun 2004 tentang Pemerintahan Daerah pada Pasal 213 ayat (1) disebutkan bahwa "Desa dapat mendirikan badan usaha milik desa sesuai dengan kebutuhan dan potensi desa". Disebutkan pula bahwa tujuan pendirian BUMDes antara lain dalam rangka peningkatan Pendapatan Asli Desa (PADesa).

Saragi (2004) dalam bukunya menyebutkan ada 5 tujuan pembentukan BUMDes yaitu: 1) Peningkatan kemampuan keuangan desa, 2) Pengembangan usaha masyarakat dalam rangka pengentasan kemiskinan, 3) Mendorong tumbuhnya usaha masyarakat, 4) Penyedia jaminan social, 5) Penyedia pelayanan bagi masyarakat desa.

Sebagaimana dinyatakan di dalam Undang-Undang Nomor 32 Tahun 2004. Oleh karena itu, setiap Pemerintah Desa dapat mendirikan Badan Usaha Milik Desa (BUMDes). Namun penting disadari bahwa BUMDes didirikan atas prakarsa masyarakat didasarkan pada potensi yang dapat dikembangkan dengan menggunakan sumberdaya lokal dan terdapat permintaan pasar. Sedangkan tugas dan peran Pemerintah adalah melakukan sosialisasi dan penyadaran kepada masyarakat desa melalui pemerintah provinsi dan/atau pemerintah kabupaten tentang arti penting BUMDes bagi peningkatan kesejahteraan masyarakat. Melalui pemerintah desa masyarakat dimotivasi, disadarkan dan dipersiapkan untuk membangun kehidupannya sendiri. Pemerintah memfasilitasi dalam bentuk pendidikan dan pelatihan dan pemenuhan lainnya yang dapat memperlancar pendirian BUMDes. Selanjutnya, mekanisme operasionalisasi diserahkan sepenuhnya kepada masyarakat desa. Untuk itu, masyarakat desa perlu dipersiapkan terlebih dahulu agar dapat menerima gagasan baru tentang lembaga ekonomi yang memiliki dua fungsi yakni bersifat sosial dan komersial.

BUMDes merupakan pilar kegiatan ekonomi di desa yang berfungsi sebagai lembaga sosial (social institution) dan komersial (commercial institution). BUMDes 
sebagai lembaga sosial berpihak kepada kepentingan masyarakat melalui kontribusinya dalam penyediaan pelayanan sosial. Sedangkan sebagai lembaga komersial bertujuan mencari keuntungan melalui penawaran sumberdaya lokal (barang dan jasa) ke pasar. Dalam menjalankan usahanya prinsip efisiensi dan efektifitas harus selalu ditekankan. BUMDes sebagai badan hukum, dibentuk berdasarkan tata perundang-undangan yang berlaku, dan sesuai dengan kesepakatan yang terbangun di masyarakat desa. Dengan demikian, bentuk BUMDes dapat beragam di setiap desa di Indonesia. Ragam bentuk ini sesuai dengan karakteristik lokal, potensi, dan sumberdaya yang dimiliki masingmasing desa. Pengaturan lebih lanjut tentang BUMDes diatur melalui Peraturan Daerah (Perda).

Sebagaimana dinyatakan di dalam Undang-Undang Nomor 32 Tahun 2004. Oleh karena itu, setiap Pemerintah Desa dapat mendirikan Badan Usaha Milik Desa (BUMDes). Namun penting disadari bahwa BUMDes didirikan atas prakarsa masyarakat didasarkan pada potensi yang dapat dikembangkan dengan menggunakan sumberdaya lokal dan terdapat permintaan pasar. Sedangkan tugas dan peran Pemerintah adalah melakukan sosialisasi dan penyadaran kepada masyarakat desa melalui pemerintah provinsi dan/atau pemerintah kabupaten tentang arti penting BUMDes bagi peningkatan kesejahteraan masyarakat. Melalui pemerintah desa masyarakat dimotivasi, disadarkan dan dipersiapkan untuk membangun kehidupannya sendiri. Pemerintah memfasilitasi dalam bentuk pendidikan dan pelatihan dan pemenuhan lainnya yang dapat memperlancar pendirian BUMDes. Selanjutnya, mekanisme operasionalisasi diserahkan sepenuhnya kepada masyarakat desa. Untuk itu, masyarakat desa perlu dipersiapkan terlebih dahulu agar dapat menerima gagasan baru tentang lembaga ekonomi yang memiliki dua fungsi yakni bersifat sosial dan komersial. Dengan tetap berpegang teguh pada karakteristik desa dan nilai-nilai yang hidup dan dihormati. Maka persiapan yang dipandang paling tepat adalah berpusat pada sosialisasi, pendidikan, dan pelatihan kepada pihak-pihak yang berkepentingan terhadap peningkatan standar hidup masyarakat desa (Pemerintah Desa, BPD, tokoh masyarakat/ketua suku, ketua-ketua kelembagaan di pedesaan).

Melalui cara demikian diharapkan keberadaan BUMDes mampu mendorong dinamisasi kehidupan ekonomi di pedesaan. Peran pemerintah desa adalah membangun relasi dengan masyarakat untuk mewujudkan pemenuhan standar pelayanan minimal (SPM), sebagai bagian dari upaya pengembangan komunitas (development based community) desa yang lebih berdaya, dengan melibatkan seluruh komponen masyarakat desa termasuk para wanita didalamnya, yang sudah terbukti berkiprah ikut mendorong perkembangan ekonomi di masyarakat serta aktif dalam kegiatan di desa ( Mutiarni R, 2016)

STIE PGRI Dewantara sebagai salah satu perguruan tinggi terkemuka di Jombang terpanggil untuk ikut serta berpartisipasi untuk mensukseskan program pemerintah di tingkat pemerintahan terkecil yaitu di tingkat desa, melalui program pengabdian masyarakat berupa pendampingan pengelolaan Badan Usaha Milik Desa (BumDes) Putra Subagyo yang terletak di Desa Miagan, Kecamatan Mojoagung, Jombang, khususnya dalam bentuk transfer ilmu pengetahun dan teknologi sistim informasi yang dibutuhkan untuk mempercepat kinerja organisasi (Mutiarni R, 2016) 


\section{Profil Mitra}

Desa Miagan adalah salah satu desa yang terletak di wilayah kecamatan Mojoagung. Mayoritas penduduk di bekerja di sektor perdagangan dan wiraswasta karena lokasinya yang berdekatan dengan pasar kecamatan Mojoagung.

Badan Usaha Milik Desa (BumDes) dibentuk pada tahun 2015 dan mulai mendapat dana dari pemerintah Jombang pada bulan Agustus 2015 sebesar Rp. 100.000.000,00 (seratus juta rupiah) sebagai dana awal pelaksanaan Badan Usaha Milik Desa (BumDes) Putra Subagyo Desa Miagan.

Mengingat keterbatasan sumber daya yang ada, maka berdasarkan musyawarah dengan perangkat desa, tokoh masyarakat dan pihak yang terkait, maka dana awal Badan Usaha Milik Desa (BumDes) dijalankan untuk usaha Persewaan Terop dan Sound System yang dikelola oleh para pengurus Badan Usaha Milik Desa (BumDes) Putra Subagyo.

Susunan pengurus Badan Usaha Milik Desa (BumDes) Putra Subagyo saat ini adalah:

1. Direktur: Bapak Antok Subagyo

2. Bendahara Ibu Sulikah

3. Sekretaris: Ibu Ika Nur Fitriyah

Kegiatan BUMDes dilaksanakan di Balai Desa Miagan. Karena kegiatan transaksi masih sederhana maka saat ini, sehingga belum disediakan kantor khusus sebagai tempat kegiatan operasional BUMDes.Struktur dan AD/ART telah tersusun sangat baik. Proses penyususan Struktur Organisasi dan AD/ART telah disepakati bersama dalam rapat rutin baik oleh perangkat Desa maupun Pengurus yang ditunjuk. AD/ART telah disepakati sebagai panduan kegiatan untuk masa tiga tahun. Ada tidaknya perubahan dalam AD/ART juga telah disepakati bisa diadakan berdasarkan hasil evaluasi terinci dari laporan oleh pengurus BUMDes dan atau perangkat desa.

\section{B. Tinjauan Pustaka}

\section{Ciri Utama Badan Usaha Milik Desa (BUMDes)}

Badan Usaha Milik Desa (BUMDes) adalah lembaga usaha desa yang dikelola oleh masyarakat dan pemerintahan desa dalam upaya memperkuat perekonomian desa dan dibentuk berdasarkan kebutuhan dan potensi desa. BUMDes menurut Undangundang nomor 32 Tahun 2004 tentang Pemerintahan Daerah didirikan antara lain dalam rangka peningkatan Pendapatan Asli Desa (PADesa). Lebih lanjut, sebagai salah satu lembaga ekonomi yang beroperasi dipedesaan, BUMDes harus memiliki perbedaan dengan lembaga ekonomi pada umumnya. Ini dimaksudkan agar keberadaan dan kinerja BUMDes mampu memberikan kontribusi yang signifikan terhadap peningkatan kesejahteraan warga desa. Disamping itu, supaya tidak berkembang sistem usaha kapitalistis di pedesaan yang dapat mengakibatkan terganggunya nilai-nilai kehidupan bermasyarakat.

Terdapat 10 (sepuluh) ciri utama yang membedakan BUMDes dengan lembaga ekonomi komersial pada umumnya yaitu:

1. Badan usaha ini dimiliki oleh desa dan dikelola secara bersama;

2. Modal usaha bersumber dari desa (51\%) dan dari masyarakat (49\%) melalui penyertaan modal (saham atau andil), 
3. Dijalankan dengan berdasarkan asas kekeluargaan dan kegotongroyongan serta berakar dari tata nilai yang berkembang dan hidup dimasyarakat (local wisdom),

4. Bidang usaha yang dijalankan didasarkan pada pengembangan potensi desa secara umum dan hasil informasi pasar yang menopang kehidupan ekonomi masyarakat,

5. Tenaga kerja yang diberdayakan dalam BUMDes merupakan tenaga kerja potensial yang ada didesa.

6. Keuntungan yang diperoleh ditujukan untuk meningkatkan kesejahteraan masyarakat desa dan atau penyerta modal.

7. Pengambilan keputusan dan penyelesaian masalah dilakukan melalui musyawarah desa

8. Peraturan-peraturan BUMDes dijalankan sebagai kebijakan desa (village policy)

9. Difasilitasi oleh Pemerintah, Pemprov, Pemkab, dan Pemdes;

10. Pelaksanaan kegiatan BUMDes diawasi secara bersama (Pemdes, BPD, anggota).

BUMDes sebagai suatu lembaga ekonomi modal usahanya dibangun atas inisiatif masyarakat dan menganut asas mandiri. Ini berarti pemenuhan modal usaha BUMDes harus bersumber dari masyarakat. Meskipun demikian, tidak menutup kemungkinan BUMDes dapat mengajukan pinjaman modal kepada pihak luar, seperti dari Pemerintah Desa atau pihak lain, bahkan melalui pihak ketiga. Ini sesuai dengan peraturan per undang-undangan (UU 32 tahun 2004 tentang Pemerintahan Daerah Pasal 213 ayat 3). Penjelasan ini sangat penting untuk mempersiapkan pendirian BUMDes, karena implikasinya akan bersentuhan dengan pengaturannya dalam Peraturan Daerah (Perda) maupun Peraturan Desa (Perdes).

\section{Maksud dan Tujuan Pembentukan BUMDes}

Maksud pembentukan BUMDes adalah :

1. Menumbuhkembangkan perekonomian desa;

2. Meningkatkan Sumber Pendapatan Asli Desa;

3. Menyelenggarakan kemanfaatan umum berupa penyediaan jasa bagi peruntukan hajat hidup masyarakat desa;

4. Sebagai perintis bagi kegiatan usaha di desa

Sedangkan tujuan pembentukan BUMDes antara lain :

1. Meningkatkan peranan masyarakat desa dalam mengelola sumber-sumber pendapatan lain yang sah;

2. Menumbuhkembangkan kegiatan ekonomi masyarakat desa, dalam unit-unit usaha desa;

3. Menumbuhkembangkan usaha sektor informal untuk dapat menyerap tenaga kerja masyarakat di desa;

4. Meningkatkan kreatifitas berwira usaha Desa masyarakat desa yang berpenghasilan rendah

Pendirian dan pengelolaan Badan Usaha Milik Desa (BUMDes) adalah merupakan perwujudan upaya memaksimalkan peran pengelolaan ekonomi produktif desa yang selama ini dilakukan oleh pemerintah desa. Peran ini perlu dilakukan secara kooperatif, partisipatif, emansipatif, transparansi, akuntabel, dan sustainable agar nantinya pengelolaan BUMDes tersebut dapat berjalan secara efektif, efisien, profesional dan mandiri 
Untuk mencapai tujuan BUMDes dilakukan dengan cara memenuhi kebutuhan (produktif dan konsumtif) masyarakat melalui pelayanan distribusi barang dan jasa yang dikelola masyarakat dan Pemdes. Pemenuhan kebutuhan ini diupayakan tidak memberatkan masyarakat, mengingat BUMDes akan menjadi usaha desa yang paling dominan dalam menggerakkan ekonomi desa. Lembaga ini juga dituntut mampu memberikan pelayanan kepada non anggota (di luar desa) dengan menempatkan harga dan pelayanan yang berlaku standar pasar. Artinya terdapat mekanisme kelembagaan/tata aturan yang disepakati bersama, sehingga menimbulkan keseragaman dari usaha-usaha yang dijalankan oleh BUMDes.

\section{BUMDes sebagai Badan Hukum}

Bumdes merupakan salah satu lembaga ekonomi desa yang diharapkan dapat menjadi sumber pendapatan desa. Untuk itu, keberadaannya harus mandapat jaminan hukum yang kuat. Hal ini sudah diperhatikan oleh pemerintah melalui Peraturan Pemerintah No. 43 Tahun 2014 (PP Desa). Dalam UU Desa dan juga PP Desa disebutkan bahwa Badan Usaha Milik Desa, yang selanjutnya disebut BUM Desa, adalah badan usaha yang seluruh atau sebagian besar modalnya dimiliki oleh Desa melalui penyertaan secara langsung yang berasal dari kekayaan Desa yang dipisahkan guna mengelola aset, jasa pelayanan, dan usaha lainnya untuk sebesarbesarnya kesejahteraan masyarakat Desa. Selanjutnya dalam Bab X Pasal 87 UU Desa diatur bahwa:(1) desa dapat mendirikan Badan Usaha Milik Desa yang disebut BUM Desa; (2) BUM Desa dikelola dengan semangat kekeluargaan dan kegotongroyongan; (3) BUM Desa dapat menjalankan usaha di bidang ekonomi dan/atau pelayanan umum sesuai dengan ketentuan peraturan perundang-undangan.

Pada pasal 88 UU Desa jo. Pasal 132 PP Desa disebutkan bahwa Bumdes didirikan berdasarkan musyawarah desa yang kemudian hasil musyawarah tersebut ditetapkan dengan Peraturan Desa. Selanjutnya dalam Pasal 135 PP Desa disebutkan bahwa modal awal Bumdes bersumber dari APB Desa yang merupakan kekayaan Desa yang dipisahkan dan tidak terbagi atas saham. Modal Bumdes terdiri dari : 1) Penyertaan Modal Desa, yang berasal dari APB Desa dan lainnya; 2) Penyertaan Modal Masyarakat Desa (Herawati, 2016)

Sebagai organisasi yang berbadan hokum, BUMDes harus mempunyai struktur organisasi yang jelas. Organisasi yang teratur ini dapat dilihat dalam Pasal 132 PP Desa yang menyebutkan bahwa Pengelola Bumdes setidaknya harus terdiri dari : 1) Penasehat; dan 2) Pelaksana Operasional. Penasehat secara ex-officio dijabat oleh Kepala Desa, sedangkan Pelaksana Operasional adalah perseorangan yang diangkat dan diberhentikan oleh Kepala Desa.

\section{Metode Pelaksanaan Kegiatan}

Kegiatan pengabdian kepada masyarakat yang dilakukan tim pendamping berupa pendampingan pencatatan transaksi hingga penyusunan laporan keuangan yang sesuai dengan standar akuntansi untuk perusahaan jasa. Kegiatan tersebut dilakukan selama bulan Pebruari 2018, berupa kunjungan resmi sebanyak 5 (lima) kali tatap muka. Selain itu, tim pendamping juga memberikan konsultasi dengan media smartphone apabila mitra mengalami kesulitan dalam pengerjaan laporan keuangan. 


\section{Hasil Kegiatan}

Pelaksanaan kegiatan pendampingan dialakukan secara intensif selama satu bulan yaitu bulan Pebruari 2018, dalam bentuk kunjungan ke desa dan konsultasi secara langsung maupun via telepon.

Pada kunjungan resmi pertama yaitu pada tanggal 2 Peb 2018, team pendamping melihat dan mengobservasi catatan transaksi Badan Usaha Milik Desa (BUMDes) tahun 2017. Dari kegiatan tersebut diketahui bahwa Petugas Badan Usaha Milik Desa (BUMDes) telah melakukan pencatatan secara sederhana meliputi transaksi kas masuk dan kas keluar dengan rinci, namun belum disusun sesuai standar akuntansi untuk jenis usaha jasa. Selanjutnya pada kunjungan kedua, team pendaping membantu Menyusun Neraca Awal pembentukan Badan Usaha Milik Desa (BUMDes), tahun 2016, serta membuat catatan pembelian perlengkapan dan peralatan. Dari hasil kegiatan ini, Petugas Badan Usaha Milik Desa (BUMDes) telah mampu memahami pengertian hata, utang, modal, perlengkapan dan pembelian. Selanjutnya, dari catatan transaksi harian, petugas Badan Usaha Milik Desa (BUMDes) dibantu untuk menyusun laporan laba/rugi untuk tahun 2017. Setelah petugas / karyawan BUMDes mampu menyusun laporan laba/rugi, selanjutnya diarahkan untuk menyusun laporan perubahan modal dan neraca untuk tahun 2017 dengan dipandu tim pendamping, yang telah menyiapkan form laporan keuangan untuk th 2017, dan menyusun buku kerja: Kas masuk, kas Keluar, laba/rugi, perubahan modal dan neraca, untuk tiap bulan. Petugas Badan Usaha Milik Desa (BUMDes) juga sudah praktik membukukan untuk tansaksi Badan Usaha Milik Desa (BUMDes) bulan Januari dan Pebruari 2018.
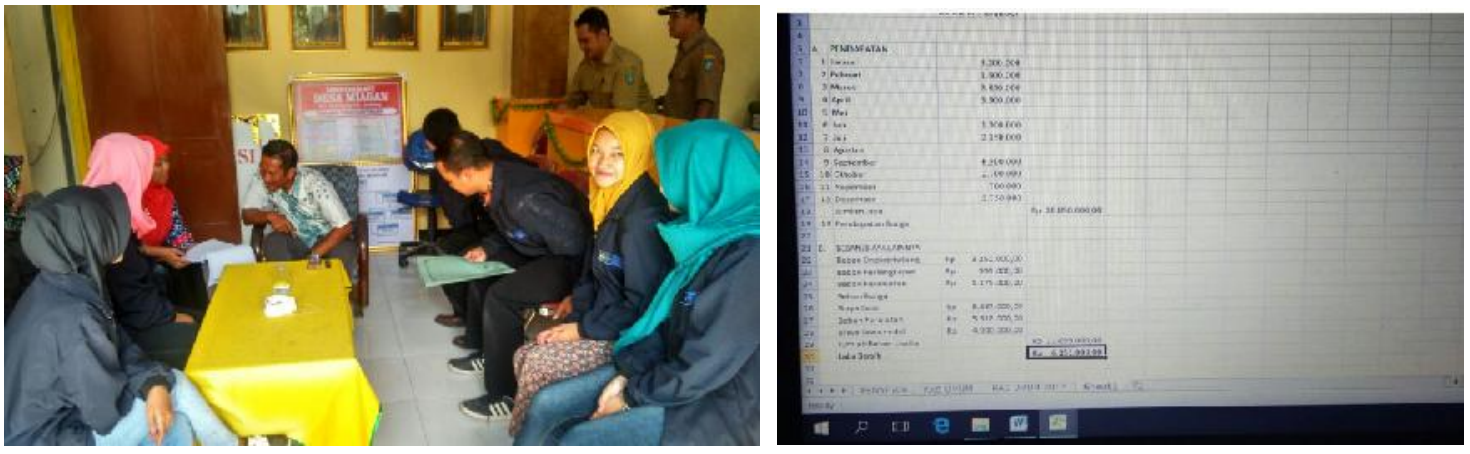

Gambar 1: Kondisi pendampingan di lapangan dan catatan sederhana BUMDes

Setelah melalui serangkaian kegiatan pendampingan yang intensif, pada kunjungan yang terakhir tim memeriksa hasil rekapitulasi kas masuk dan keluar serta penyusunan laporan keuangan bulan Januari dan Pebruari. Petugas/ karyawan BUMDes) telah mampu melanjutkan pencatatan transaksi hingga penyusunan laporan keuangan dengan rapi dan benar untuk bulan Januari 2018. Karyawan Badan Usaha Milik Desa (BUMDes) juga berkonsultasi tentang pekerjaan yang telah dilakukan. Petugas Badan Usaha Milik Desa (BUMDes) telah membuat laporan sampai dengan Pebruari dengan benar. Selanjutnya, team pendamping akan tetap melakukan pendampingan sampai dengan akhir tahun 2018 apabila diperlukan. 


\section{E. Penutup}

Dari seluruh rangkaian kegiatan pendampingan yang telah dilakukan, bisa disimpulkan bahwa Badan Usaha Milik Desa (BumDes) Putra Subagyo di Desa Miagan yang bergerak di bidang usaha jasa berupa persewaan terop dan sound system, telah melakukan sistim pencatatan transaksi yang sudah rapi tetapi belum sesuai standar akuntansi keuangan. Melihat dari kondisi tersebut, maka tim pendamping fokus pada kegiatan pendampingan pencatatan transaksi hingga penyusunan laporan keuangan setiap bulan, yang sesuai dengan standar akuntansi untuk perusahaan jasa. Setelah dilakukan pendampingan, pengurus bisa melakukan pencatatan transaksi hingga pembuatan laporan keuangan sesuai standar akuntansi keuangan.

Maka dari Simpulan diatas disarankan kepada pihak pengurus Badan Usaha Milik Desa (BumDes) Putra Subagyo agar meneruskan sistim pencatatan transaksi hingga pembuatan laporan keuangan sesuai dengan materi yang telah diberikan pendamping. Selain itu, kepada pemerintah desa setempat untuk lebih memperhatikan perkembangan Badan Usaha Milik Desa (BumDes) agar unit usahanya bisa berkembang dan tidak hanya sebatas usaha persewaan terop dan sound system.

\section{DAFTAR PUSTAKA}

Herawati, E. (2016, Oktober). Binus business-law. Retrieved April 2018, from Binus Business Law Web site: http://business-law.binus.ac.id/2016/10/16/badanusaha-milik-desa-status-dan-pembentukannya/

Mutiarni, R., Utomo, L. P., \& Zuhroh, S. (2017). Pendampingan Pencatatan Transaksi Keuangan Pada Koperasi Bunga Harapan Desa Ceweng. Comvice: Journal Of Community Service, 1(1), 33-38.

Mutiarni, R. (2017). Implementasi Electronic Data Processing Pada Koperasi Wanita. Eksis: Jurnal Riset Ekonomi dan Bisnis, 12 (2 Okt), 135-148.

Undang-Undang, R. I. No. 32 tahun 2004 tentang. Pemerintahan Daerah.

Indonesia, R. (1999). Undang-Undang No. 8 Tahun 1999 Tentang Perlindungan Konsumen. Lembaran Negara RI Tahun, (8). 